\title{
British Early Intervention in the Slave Trade With Oman
}

\section{2-1873}

\author{
Yusuf A. Al Ghailani \\ Sultan Qaboos University
}

\begin{abstract}
This study tackles the considerable role played by the slave trade in Oman (between 1822-1873). It also shows the direct relation between this trade and the active role played by the British government in suppressing this trade, which was supported by the law decreed by the British Parliament in 1807. This law declared the abolition of the slave trade considering in illegal in all ports under British jurisdiction and decreed a punishment of exile to all persons involved in this trade. In these circumstances Oman became one of the countries concerned and interested to work and cooperate with the British authorities to end this trade. This was shown in a number of treaties such as the treaty of 1822, 1839, 1845 with the Imam of Oman Sayyid Said bin Sultan and the treaty of 1849 with the Governor of Sohar, Sayyid Saif bin Hamud. These treaties gave the British Government, as represented by its fleet in the Indian Ocean the right to check, inspect and confiscate any Omani ship found involved in the slave trade. This research also illustrates the role of the Omani government in enforcing these treaties by pursuing and bringing to court all those who were found guilty practicing this trade. One of the main subjects discussed during the period of study is the number of ships involved in this activity, the number of slaved carried by these ships and the legal measures taken against the owners of these ships. Both British and Omanis worked together to find effective ways and means to stop this trade. Finally this study depended on a number of British documents both published and unpublished as well as other European sources.
\end{abstract}

Keywords: Oman, British, Slave-Trade with Africa, treaties, ships

In dealing with the issue of the slave-trade in Oman, or in any part of Arabia and the Persian Gulf, we should remember the attitude of the people towards the question, and the morality of its legitimacy. The topic is very sensitive and affected a large part of other Gulf States populations, as well as the people of Oman. The trade played a major role in Arabia during the eighteenth, nineteenth, and part of the twentieth century.

In fact the traffic in this business was considered illegal by most of the people who were involved in it. It was certainly not favored by Islamic law, which encourages at belief in freedom, justice, and equality. However, those who were involved in the trade were illiterate in Islamic thinking and as result of the harsh circumstances of their lives, the demands of their societies, and the small size of the population; they found themselves in absolute need to have these people to help them either in overseas trade or working on the land. A proportion of the slaves were brought from their original lands for the purpose of trading in them. There was another fact which persuaded the

Yusuf A. Al Ghailani, Sultan Qaboos University, Oman. 
Arabs to become involved in this illegal trade, which was that slaves had been brought to the markets of East Africa by the black people themselves, who sold them either for money or goods to the Arab traders.

The trade in black people from the East African Coast was mainly considered as a form of trade between Zanzibar and its dominions on one hand and the coasts of Arabia and the Persian Gulf on the other hand; and by far the largest portion of the traffic was taken to the Arabian Peninsula through three different stages, before it reached its final destination.

These were the land journey from their original homes inland to the coast; secondly a short trip across the sea to Zanzibar, where the main open slave market was held; and thirdly the final sea journey from Zanzibar to Arabia or any other part of Asia. ${ }^{1}$ In fact this was the case with the traffic in Zanzibar, where these three stages were sometime reduced to two only, when slaves passed from Mozambique, Pemba, Dar-es-Salaam, Kilwa, and Mombasa to Zanzibar. Kilwa was the principal port of shipment for Zanzibar and its dominions, but sometimes they could be shipped directly from Kilwa to the northern Po.

\section{Early British-Omani Involvement Against the Traffic}

During the first half of the nineteenth century, the British Government gave active attention to preventing those who were dealing in this trade. ${ }^{2}$ They concluded a series of treaties with the Shaikhs of the Trucial Coast, Oman, Bahrain as well as the Persian Government, from 1822 onwards for the purpose of the suppression of the traffic in slavery, which however, remained in force until sometime during the twentieth century and to maintaining perpetual peace in Arabian waters. ${ }^{3}$ Since there was no strong local authority to watch the activities in slavery, the British adopted the policy of on their own responsibility. However, activities on this issue required the continual of British men-of-war along the Coasts of Arabia and the Persian coast as well. ${ }^{4}$

Oman had become a partner with the British in the continuing commitment to the suppression of the traffic in the area, and was encouraged by them to induce its subjects to refrain from this illegal trade. On 10th September 1822, the Imam of Muscat, Sayyid Said b. Sultan, entered into a formal engagement for a definite abolition of the slave-trade, between the dominions of His Highness and Christian countries, which was considered as a great step towards an understanding between Oman and Great Britain about the suppression of the trade. ${ }^{5}$ Hereby the treaty of commerce between Her Majesty the Queen and His Highness the Sayyid of Oman which had been concluded on 31st May 1839 had attached to it three additional Articles regarding the abolition of the foreign slave-trade. ${ }^{6}$ In this engagement the Imam submitted his acceptance of the Articles of the above mentioned Treaty which had been signed at Zanzibar, by him and the British representative Captain Moresby.

In fact a strong anti-slavery campaign had been conducted in England since the end of the eighteenth century, when action against this matter was largely supported by the British people, who then wanted to impose prohibition upon the rest of the world. By the year 1807, a law had been passed by the British Parliament

\footnotetext{
${ }^{1}$ Parliamentary Papers. vol. lxii. 1871. See the Select Committee Report on, Slavery.

2 Ibid. See the same Report.

${ }^{3}$ Mss. 12593. See Enclosure iii to xv. Addressed by His Excellency the Viceroy at a Durbar held on board H. M. S. Argonaut on 21st November 1903, at Sharjah for the Arab Chiefs of the littoral.

${ }^{4}$ For further information see Olson, W. J., Britain's Elusive Empire in the Middle East, 1900-1921. London; 1982, pp. 32-33; see also Philby, H., Arabian Jubilee. London; 1952. p. 165.

${ }_{5}^{5}$ Tuson, P. \& Quick, E.; (eds.) Arabian Treaties 1600-1960. vol. iii, Oman and Yemen, London; 1992. pp. 46-47.

${ }^{6}$ Ibid. p. 47.
} 
prohibiting the slave-trade and making it illegal for any vessel to collect slaves from a port in the British dominions after 1st May 1807. ${ }^{7}$ In 1811, the traffic in slavery was announced to be a crime whose punishment would be transportation; the prohibition of the trade with British subjects had recently been violated, when slave traders succeeded in delivering one of three consignments to Arabia. This fact induced the British Government to consider this trade as a crime, and to produce this new law of $1811 .^{8}$

The additional Articles of the 1839 Treaty authorized British Government cruisers to search and detain any suspect vessel belonging to the Imam's subjects, from Cape Delgado on the East African Coast to the Persian Gulf. ${ }^{9}$ If any such vessel was found to be involved in this trade British cruisers would be obliged to capture it and confiscate its cargo. In accordance with this understanding, the British Government held the Imam to be engaged under their policy and took it for granted that it would produce a major effect in preventing piracy and the slave-trade in the Imam's dominions. They also considered this action as a suitable one for maintaining control over the traffic in the Persian Gulf and Oman simultaneously. Meanwhile the British Government had found itself in a position in which it could watch over the peace of the Gulf and ensure at all times the observance of the treaties in the region, the main objective for the British being to prevent the people of the area from being involved in the traffic, and warning them against neglecting or infringing its provisions.

The Imam of Muscat was the one who could participate with the British against this matter, as he was the only one who had a powerful influence to deal with the progressive increase of the traffic. At the same time he was the authority whose dominions were always considered as one of the main nation involved in this problem. Accordingly the British Government confirmed his orts to co-operate with them, and his successors thereafter. In continuation of their efforts to that purpose, another agreement between His Highness the Imam and the British Government of Her Majesty the Queen for the termination of the export of slaves from the African dominions of the Sultan of Muscat, was concluded at Zanzibar on 2nd October, $1845 .{ }^{10}$ The two Governments agreed to the objective that the export of slaves from the Sultan's dominion should stop, and the Sultan of Muscat had no objection to the British wishes, for the humanity sake. He entered into that agreement which made further prohibition on the export of slaves from his African dominions, since the British wished to put an real end to the slave trade. The British Government authorized Captain Atkins Hamerton to conclude the treaty with the Sultan of Muscat Sayyid Said b. Sultan. ${ }^{11}$

The agreement concluded with four Articles concentrated upon further engagements to prohibit, under the severest punishment, the export of slaves from the Sultan's African dominions, while he should take effective action to prevent the traffic practically. The importation of slaves from any of the Sayyid's dominions in Africa to his possessions in Asia should also be prohibited, and he should use the greatest possible influence with all the chiefs of Arabia, and the Persian Gulf, to halt the traffic in slavery in their territories, and to stop the introduction of slaves from Africa into their respective dominions. ${ }^{12}$

\footnotetext{
${ }^{7}$ Lorimer J. G., Gazetteer of the Persian Gulf; Oman and Central Arabia. Calcutta, 1915. Vol. i. p. 2475. See also Records of Oman. vol. vi, pp. 298-299.

${ }^{8}$ Lorimer, 1915, vol. I, p. 2475; R. O. vol. vi, p. 299.

9 Aitchison, C. U. A Collection of Treaties Engagements and Sanads Relating to India and Neighbouring Countris. 1983, vol. xi, pp. 299-300.

${ }_{10}^{10}$ R. O. vim pp. 337-338.

11 Aitchison, 1983, vol. xi, p. 300. See also R. O. vol. vi, p. 338.

12 Tuson \& Quick, 1992, vol. iii, p. 73; Aitchison, 1983, vol. xi, p. 300. See also Lorimer 1915 vol. i. p. 2477.
} 
The treaty of 1845 came into effect on 1st of January 1847, and as a result from then onwards the Sultan agreed to allow the Royal Navy to watch, capture, and confiscate any Omani dhow found involved in this criminal trade. ${ }^{13}$ At this stage the sultan of Oman showed his desire to co-operate on vigorously with the British to build a gradual obstacle in the way of this crime. He had come to the conclusion that under this engagement, with the threat of the severest punishment, the export of slaves from Africa would be prevented.

On 15th September 1848, an Act was carried into effect for an Agreement between the British Government and the Government of Oman to bring more influential action, upon those who were still dealing in slavery and to promote effective suppression of the slave trade as a whole. ${ }^{14}$ Although the added pressure upon the trade brought undisputed British action against the tragic in the Sultan's dominions, and the slavers became exposed to search, confiscation, and detention by the Royal Navy, the activities of the traders had remained successful.

The Treaty of 1848 further engaged the Sultan of Muscat to prohibit the importation of slaves from any part of Africa into his territories in Asia, and authorized the British Navy to take sufficient action in accordance with its terms to catch core slave vessels at sea. The Agreement also gave great power to the commanders of H.M. ships to stop and board any vessel belonging to the Sultan of Muscat's subjects, within certain limits, suspected of being involved in this traffic.

On 22nd May 1849 the governor of Sohar, sayyidsaif b. Hamud, signed his engagement with the British Resident in the Persian Gulf Major Hennell, on behalf of the British Government, Designed to prohibit the exportation of slaves from East Africa and elsewhere on board vessels belonging to his subjects. ${ }^{15}$ He also agreed to authorize British men of war to search and detain any such vessel which they suspected of being involved in the slave-trade, and to confiscate them if the suspicion was confirmed. The agreement was approved by the British Government on 4th August 1849. ${ }^{16}$

On 4th November 1867 a Muscat Order in Council authorized the British Agent at Muscat to try any British subjects accused of taking part in the trade, or of being an accomplice in the purchase or sale of slaves, or of having slaves illegally in their ownership, or otherwise to send them to India for trial by the High Court in Bombay. ${ }^{17}$

This engagement was an additional step which enabled the British Government to increase their pressure on the trade and to be assured through the activities of the Royal Navy of supporting the authorities in Oman against any infringement against these Treaties. Officially these agreements had now confirmed the position of absolute prohibition of the slave-trade, and abolished the open slave markets in these territories.

\section{The Slave-Trade and British Remarks in the 1860s}

\section{British Attempts at Control}

Despite the campaign against the East African slave-trade and the Sultan of Muscat's efforts in that regard, the traffic continued on the seas between the East African Coast and Oman, not only by Arabs, but also by British

\footnotetext{
13 Aitchison, 1983, vol. xi, p. 301.

14 Tuson \& Quick, 1992, vol. iii, pp. 77-78; See also Lorimer, 1915, vol. I, p. 2478.

15 Tuson \& Quick, 1992, vol. iii, p. 85. Lorimes, 1915, vol. i, p. 2478.

16 Tuson \& Quick, 1992, vol. iii, p. 85.

${ }^{17}$ F. O. 54/28. British Order in Council, for regulation of British Consular Jurisdiction within the Dominions of the Sultan of Muscat. November 4th 1867.
} 
Indian subjects. In confirmation of this fact, Captain Rigby, H. M. Consul and British Political Agent at Zanzibar, reported to the Secretary to the Government of Bombay, N. L. Anderson, in April 1859 that he had recently ascertained that several British Indian subjects residing at Zanzibar were still in the habit of trading in slaves despite his efforts to restrain them from doing so. ${ }^{18}$

In fact the Indian native traders had already received the prohibition of the British consul at Zanzibar against the holding of slaves, when he started to imprison the slave-traders and to free the slaves held by the Banians (British Indian Natives). ${ }^{19}$ This step which had been carried out by the Agent at Zanzibar was disputed by his successor, and when the question was submitted to the Government of Bombay, it was clarified that those subjects of Native States who might declare themselves to be under the authority of the Sultan should not be interfered with. Some of the traders took advantage of this, and began to buy and sell slaves. ${ }^{20}$ Although the Indian traders had been pressured not to be involved in the traffic, it continued among them and some Arabs for the time being. The British Government concentrated on enforcing preventive measures against this trade, to complete their action on the suppression, which certainly was not achieved at once; the traders' dhows from Oman and Arabia seemed unlikely to be removed from these coasts in the short term.

Possibly the largest capture of slaves in 1859 was the seizure of a dhow from Mukalla on the coast of Arabia with 44 slave boys on board, whose master was forced to sail to Lamu on the Kenyan coast, one of the ports within the Sultan of Zanzibar's dominions. The slaves were brought to the town to be liberated, and the Nokhada (the dhow's master) was imprisoned in its fort. ${ }^{21}$ Following this incident the Sultan of Zanzibar was ordered to explain clearly that under no circumstances could a slave be shipped on board any Baghlah (kind of Arab boat), no matter where bound, unless this boat belonged to a port in the Zanzibar dominions. The Sultan also summoned all the slave brokers and strictly forbade them to sell a slave to any stranger or any other person whatsoever, unless they knew him to be a subject of Zanzibar. This was generally proclaimed throughout the town of Bamba, and it was also announced at the same time that any of the Sultan's subjects found carrying a slave to any port of the coast of Africa would be arrested and be brought for trial. ${ }^{22}$

Meanwhile the Sultan had bound himself to watch for the export of slaves from his territories to Muscat, and any boarding of slaves on any Arab Baghlah. The importation of African slaves by sea to Muscat dominions was now officially prohibited, but the legal position was being ignored, and the slave-trade from Africa to the coasts of Arabia and the Persian Gulf unfortunately continued their activity in vessels belonging to subjects of those areas, under the Turkish and French flags, which was contrary to the laws of the Shaikhs of the Trucial Coast, but not those of Qatar, Hasa, and Kuwait. ${ }^{23}$

Mukalla on the Arabian Coast and some ports in Oman were accused of being involved in the trade from East African Coasts, and a dominating this traffic in the rest of the Arabian Peninsula and the Persian Gulf. At the

\footnotetext{
18 I. O. R. UP\&S/5/502. Letter No. 52 of 1859 from H. M. Consular and British Agent at Zanzibar to N. L. Anderson the Secretary to the Government of Bombay. April 1859.

${ }^{19}$ Saldanha, I. A., Précis on the Slave Trade in the Gulf of Oman and the Persian Gulf 1873-1905, with a Retrospect into previous history from 1856. Simla; 1906. p. 16.

${ }^{20}$ Ibid. pp. 16-17.

${ }^{21}$ I. O. R. L/P\&S/5/502. Enclosure from Colonel Rigby, the Agent and Consul at Zanzibar, to Anderson the Secretary to the Government of Bombay. Zanzibar, April 1859.

22 I. O. R. Up\&S/5/502. See the same Enclosure.

23 Saldanha, 1906, pp. 110-111; Lorimer, 1915, vol. i, pp. 2484-2485.
} 
same time Muscat was also accused of being an extensive re-export center for the trade in slaves to some ports in the Gulf and the Mekran Coast. The British pressure to reduce this traffic continued effectively and was demonstrated by the Political Resident in the Gulf, Lewis Pelly who forced Sayyid Majid of Zanzibar to be more active in his opposition to the activities of the trade.

In October 1863, Sultan Majid issued an order to prohibit the export of slaves from Kilwa, another port of his dominions on the African Coast, during the seasons of the Arab visits to the East Africa coast. In January 1864, this order was extended to all of his dominions in Africa. ${ }^{24}$ The British attempts to stop the trade had become an essential feature of their policy, not with the Sultan of Muscat only but with Majid as well. Traders' dhows sailing under the Sultan's flags were considered an easy target for search and detention. However, the trade actually remained in existence, as measured by British success in the capture of slaves and slavers on the high seas; capture was undoubtedly the major threat to those who still carried on the trade.

The number of slaves who reached the Arabian and Persian Coast after the 1850s was considerably decreased compared with that during the 1830s and 1840s, but the smugglers managed to escape capture and deliver small numbers to their territories on the African Coasts. Though it is difficult to give a reliable or exact estimate of the number of slaves who reached their final destination during the 1840s and 1850s, the yearly figures could reach between 10,000 and 20,000 persons. $^{25}$

In 1850 Kilwa was considered the most important town on the coast between Mozambique and Zanzibar, and the largest trading center in East Africa. In 1851, the American Consul at Zanzibar, Charles Ward, estimated the annual rate of importation of slaves to Zanzibar to be between 8,000 and 10,000, the majority of them arriving from Kilwa. ${ }^{26}$ At Zanzibar the slaves could be sold either in the open market or direct to the slave-traders, and then shipped to Arabia and the Persian Gulf, where a ready market was found for slaves, the total export of slaves not smuggled from Kilwa in the five years 1862-1867 was about 97,302, and the following table shows the export through the Custom-House for that period. ${ }^{27}$

Table 1

Export of Slaves, to Zanzibar, Arabia and the Persian Gulf

\begin{tabular}{lll}
\hline Year & Zanzibar & Elsewhere \\
\hline $1862-63$ & 13,000 & 5,500 \\
$1863-64$ & 14,000 & 3,500 \\
$1864-65$ & 13,821 & 3,000 \\
$1865-66$ & 18,344 & 4,000 \\
$1866-67$ & 17,538 & 4,500 \\
\hline
\end{tabular}

The attitude of the Government of Bombay towards the slave-trade was based on what their Agent at Zanzibar had seen that the traffic did not seem to be suppressed at once and by one action only. He stated that the captures of slaves on the seas by the officers of British Cruiser were fewer than expected and in general had not

\footnotetext{
24 Beachey, R. W., The Slave Trade of Eastern Africa. London; 1976. pp. 48-57.

25 Saldanha, 1906, pp. 100-111; Kelly, 1968, pp. 412-414; Bhacker, M. R.,1988 Roots of Dependency, British Reaction towards the Development of Omani Commerce at Muscat. (Ph.D. Thesis), Oxford University, England. pp. 189-190.

${ }^{26}$ Bader Z., 1991, "The Contradictions of Merchant Capital 1840-1939”, (eds.) Abdul Sheriff \& Ferguson, Zanzibar under Colonial Rule, London. p. 167.

27 Parliamentary Papers. Report of the Select Committee, 4th August 1871. vol. lxii, 1871.
} 
had a good effect. The trade was illegal and contrary to the treaties signed by the British with the region's authorities, and should be considered as a social disaster and a humiliation by those who were still dealing with it. ${ }^{28}$ Despite this the trade was now struggling to find a free market, though the marketing of human beings was entirely against the wishes of the British and their partners in Oman who strongly confirmed its prohibition. There had always been great concern about the traffic's progress, and though a considerable number of slaves were yearly imported from East Africa they were not always taken to Muscat or to any of its territories, but to different places in the Gulf, and then were transferred to further destinations such as Basra, the Turkish dominions, and even to India. ${ }^{29}$

During the years following the appointment of Lt Col. Rigby as the Agent in Zanzibar, the traffic notably increased. He was at full liberty to direct all his activities towards the suppression of the slave traffic in East Africa. ${ }^{30}$ However, it was presumably not an easy task to achieve completely, nor to stop a long established custom. Apparently the British ships which sometimes succeeded in seizing slaves on board dhows as they set sail faced a very difficult task. The British authorities' views on the suppression of the traffic reflected their anger and anxiety as they were dealing with only a small part of this illegal trade.

\section{Intensified British Efforts in the Matter}

During the early 1860s, the British Political Agent at Zanzibar confirmed to both the Foreign Office and the Government of Bombay the great spread of the slave-trade. Until very recent years the dhows which carried slaves had merely carried a few in addition to legitimate trade, but by the year 1861, the numbers of slaves shipped in a single dhow were ranging between 100 and 200. In that year a single trading vessel with about 273 slaves on board was captured by H.M.S. Sidon. In the same year H.M.S. Lyra arrived at Zanzibar, and the Agent, Lt. Col. Rigby, immediately requested her commander to remain in this port for the purpose of watching the coast. ${ }^{31}$ The commander of the Lyra took energetic steps, and managed during its presence in that port to destroy at least 16 trading dhows, and to free 250 slaves. ${ }^{32}$ The Lyra joined with the Indian Navy Ship Sidon and together they patrolled the African Coast to the north of Zanzibar during the season of the south east monsoon. ${ }^{33}$ By the end of 1862, there was a development with regard to the maintenance of the British interests in the Indian Ocean, when the Secretary of State for India agreed to transfer all the responsibilities of the Indian Navy to Royal Navy duties. Sir Charles Wood also agreed to send the Pleiad to Zanzibar and then allowed it to proceed to Aden, and the Clyde and the Sir Hugh Rose were sent to the Persian Gulf, and allowed similar deployment for Aden. ${ }^{34}$

Under these circumstances Lt. Col. Rigby urged the British Government to follow up their action against the trade, by continued patrols of H.M.S. Lyraand sidon, by which during the second half of 1862 they managed to catch 25 dhows transporting slaves to the coasts of Arabia, which was unchecked by the Zanzibar authorities. ${ }^{35}$ In fact the slave-trade remained an attractive business for those who dealt with it, not among the Arabs alone but

28 Alpers, E. A., 1975, Ivory and Slaves in East Central Africa. Nairobi. pp. 236-237.

29 Martineau, I. 1895, The Life and Correspondence of Sir Bartle Frere .vol. ii, London. pp. 504-505.

30 Russell, C. E. B., 1935, General Rigby, Zanzibar and the Slave Trade. London. pp. 181-82; Saldanha, 1906 , pp. $110-111$.

31 Coen, T. C., 1971, The Indian Political Service. London. pp. 232-233; Kelly 1968. p. 618.

32 Russel, 1935, p. 182.

33 Kelly, J. B., Britain and the Persian Gulf 1795-1880. p. 618; Datoo, B. A., 1970, "Misconceptions about the use of the monsoons by Dhows in the East African Waters” East African Geographical Review. no. 8, pp. 2-6.

34 Saldanha, J. A., 1906, Precis on Naval Arrangement in the Persian Gulf 1862-1905. Slmla, p. 11.

35 Russell 1935, pp. 186-187. 
the Africans and the Indians as well, when the selling price was always at a notable profit. On the 13th May 1864 the Government of Bombay forwarded a suggestion to the Government of India made by the Resident in the Gulf and his colleague Lt. Col. Rigby, the British Agent at Zanzibar, for more effective action against the traffic in slaves. $^{36}$

Although there was remarkable action by sea against the traffic at this stage, its legal continuity from the East African mainland and Zanzibar mounted great obstacles to the prevention of smuggling from Zanzibar to the Arabian Coasts. During the visit of Brigadier W. M. Coghlan to Muscat for the preparation of the ZanzibarMuscat Arbitration in 1861, SayyidThuwaini b. Said told him that he strongly believed that no effective action could be achieved against it if the trade remained lawful between the East African mainland and Zanzibar under the provisions of the treaties signed with his father Sayyid Said b. Sultan. ${ }^{37}$ However agreement in these areas to solve the problem presented great difficulty, but Muscat and Zanzibar were both in a position in which they could not refuse a British request for the greater co-operation which seemed necessary to abolish this practice.

In accordance with this, the India Office wrote to the Sultan of Muscat, SayyidThuwaini, on 18th December 1863 with copies of the two treaties concluded by Brigadier Coghlan with the Chiefs of MukallaSalih b. Muhammed and Ali b. Najeeb, the Governor of Shihar. The British felt that it was necessary for them to inform the Sultan of Muscat and Zanzibar of the wishes of these Chiefs, which should be fulfilled. ${ }^{38}$

Captain P. Colomb, who had been appointed to command the British cruisers from 1862-70, declared that there were a number of dhows dealing with the transfer of slaves, each of which could carry from 100 to 150 slaves to the Arabian and the Persian Gulf Coasts. These dhows were usually mastered by Arabs, while their crew were mostly Africans who were not for sale and who managed their own funds and traveled freely with their Nokhada. ${ }^{39}$ In 1868, Captain Colomb was appointed to the command of H.M.S. Dryad and joined his cruiser at Aden, which was one of the important ports involved in this activity. Thus British ships were now being seen cruising off the southern coast of Arabia for the first time. ${ }^{40}$ From now onwards the Royal Navy carried on its intensive patrolling against the smuggling traffic conducted by sea by the Arabs, and five ships including the Dryad were searching the dhows carrying slaves from Africa to Asia. These operations succeeded in watching all along the southern shores of Arabia, to anticipate vessels heading for the Gulf of Oman. ${ }^{41}$ However, the result of these activities was not entirely encouraging, as these ships were able to catch only 32 Arab dhows carrying a total of 1,117 slaves on board, whom they liberated immediately, while the number of slaves who were exported from East Africa to Arabia during the period from 1867 to 1869, exceeded 37,000, and only 2,645 were freed. ${ }^{42}$ The total effect of these measures was not encouraged yet, but the British determination to put an real end to this crime caused a significant troubles for the trade future and notable inconvenience among the traders.

The British Officer had come to the conclusion that the dhows were discharging their consignments further south along the Arabian coast, and he found that it would be a better plan for the Royal Navy to extend its

\footnotetext{
36 Saldanha, Precis of Naval Arrangements. p. 12.

37 Kelly, 1968, p. 615.

${ }^{38}$ I. O. R. UP\&S/5/597. Letter from the India Office, London, to Her Majesty’s. Consul at Muscat, Lt. Col. H. Disbrowe. Dated, 18th December 1863.

39 Harris, J. E., 1971, The African Presence in Asia. Evanston. p. 31.

40 Beachey, 1976, p. 74.

${ }^{41}$ Miers, S., 1975, Britain and the Ending of the Slave Trade. London. p. 90.

42 Lloyd, C., 1949, The Navy and the Slave Trade. London. p. 202.
} 
operations from RasMadraka and Ras al-Hadd on the Omani Coast to Cape Guardafui on the Somali coast. ${ }^{43}$ The action against slavery had drawn the Omani officials closer to the matter, and the British Government found that the Government of Oman was desired to enforce the anti-slavery action, as it was obliged by the previous treaties signed by the Sultan Said b. Sultan with the British. ${ }^{44}$ The Suri people were the Omanis most accused of being heavily involved in the slave trade from the East African coast to Oman and the Persian Gulf, though the Arabs of the Gulf themselves were also very active in importing and re-exporting slaves to and from their dominions. ${ }^{45}$ However, Sur was considered the largest slave trading port in the Arabian Sea, which was confirmed by its activities during the following years.

\section{New British Tactics Against the Traffic}

The British took the matter more seriously after the year 1868. On 22nd January 1870 Commander Sir L. Heath reported to the Secretary to the Admiralty confirming the report sent in 1869 regarding the new British deployment of Royal Navy ships along the trade route to Arabia. He submitted in information that the ships which were available in the Spring of the year 1869 for the service against slave traders were the Fort, Daphne, Star, Nymph and Dryad; these vessels all remained in Bombay during the winter months, except the Nymph, which left for Zanzibar to watch the British interests there against the anticipated troubles from the Northern Arabs, and the Dryad which had been sent to the Persian Gulf to support the Resident. ${ }^{46}$ In accordance with this situation, by April 1869 the Armed Navalships were in position: the Italic guarding from Ras al-Hadd to KuriaMuria Islands, the Daphne guarding from KuriaMuria to Mukalla, and the Fort working along the Coast between the two. Star guarded from Socatra to Cape Durnford. The ships remained on the stations until the monsoon became too strong, and after taking their captives to Aden most of them preceded to the Mozambique Channel, where they were joined by the Cossack and Bullfinch. ${ }^{47}$

Sir L. Heath also confirmed the general information on the success of that year's work, in which the Officers of the Squadron had shown great enthusiasm and energy to fulfill their job successfully. They had been able to board a number of dhows excess of 400 , including which were boarded more than once. ${ }^{48}$ Notwithstanding the fact that the number of slave trading vessels destroyed during the year was 32 less than that of 1868, which totaled 66, the number of liberated slaves was higher by about 20 persons than the 1,097 freed in $1868 .^{49}$

The British officials were faced with some trouble regarding the traders who were residing in Muscat and its territories. These were numerous, and claiming to be British subjects, while the British Resident in the Gulf accused the Government of Muscat of being part of this problem as they did not recognize them as British and their nationality had not been resolved by the Government of Bombay. However, the nationality of these traders required careful and conciliatory decision, and after the settlement of this matter the Resident recommended the registration of the names of those who might be recognized as British subjects. ${ }^{50}$ He was absolutely convinced

43 Beachery, 1976, p. 75.

44 Miles, S. B., 1919, The Countries and the Tribes of the Persian Gulf. London. p. 476.

45 Saldanha, Precis on Slave Trade. pp. 110-11. c.

46 Parliamentary Papers. vol. xii 1871. Report No. 54. Bombay, 22nd January, 1871.

47 Ibid. See the same Report.

48 Ibid. See the same Report.

49 Parliamentary Papers. vol. lxi, 1870 and vol. xii, 1871. Parliamentary Committee Report on Slave Trade; Lioyd, 1949 , p. 202.

50 I. O. R. UP\&S/9/42. Letter No. 75/41 of 1871 from Lt. Col. Lewis Pelly [PRPG], to Major A. Way. the Acting Political Agent at Muscat. Bushire, 23rd April 1871. 
that a large number of these people had been involved in the slave-trade activities, while their Government was considerably involved in the suppression of the trade. It was now ascertained that the British Consul had a right to be involved directly against any illegal action carried out by British subjects, who usually escaped lawful prosecution when they committed these activities beyond British jurisdiction. ${ }^{51}$

\section{Early British Success in the Matter}

By the year 1870, the British Government had become certain of their success in controlling the slave importation to Arabia. In the same year the Royal Navy made good progress by capturing seven dhows out of 40, near Ras-Hafun on the Somali Coast, which they held awaiting before setting sail from Zanzibar. ${ }^{52}$ The major problem which faced the British in catching the vessels at sea was the flying of foreign flags by trading dhows, like the French colour which became popular for use by the traders.

The British however, concentrated their anti-slavery effort in the traffic area, and they did quite reasonable work to stop the traffic. The search for help from the local Arabs Governments, and the Government of Oman especially, was said to be practical by the authorities. Thus British interference with a long established social custom in Arab society seemed to be a very challenging task without the approval of public opinion to prohibit the traffic. Local people had been familiar with this traffic as an institution from the early 18th century, and with the use of African slaves. ${ }^{53}$ Despite the British action on this matter, the trade continued in progress on a large scale, as did the export fro Zanzibar and Kilwa, the main ports from which the slaves were shipped in many different directions.

On 1st February 1870 J. Kirk, the British Political Agent and Consul at Zanzibar, reported that approximately 14,944 slaves were exported from Kilwa in the year 1869, and that slaves liberated from dhows had usually been sent in the late 1860s to Aden and Bombay. ${ }^{54}$ The object of the British Government in being involved in these activities against the trade by adopting treaties with the Arab Governments was to avoid interference with domestic slave-trade in the dominions of those rulers, and to force local control of the issue. Accordingly they wished the treaties with the Sultan of Muscat to be binding upon the Sultan of Zanzibar, who acknowledged these facts by issuing an order preventing the export of slaves from Africa, as well as their import from Africa into Asia, but he permitted the import of slaves between Kilwa and Zanzibar. As a result the British remained active in carrying out their measures to limit the shipment of slaves from the mainland to Sultan of Zanzibar's dominions. ${ }^{55}$

The British could not assume that the trade would be completely eradicated. The object of the Parliamentary Select Committee was to prohibit the traffic in slavery, and to produce a considerable obligation upon the Sultan of Zanzibar to suppress the trade in his sphere of influence or at least to limit it. They used all legitimate action to put an end to the slave trade without any interference in the interior affairs of Zanzibar. Sir T. Fowell Buxton, from the Parliamentary Select Committee, confirmed that the transport of slaves between Zanzibar and its dominions offered cover for foreign traders, who procured at Zanzibar or Kilwa the requisite port clearances and

\footnotetext{
${ }^{51}$ For further information on this issue see British Order in Council, for the Regulation of the British Consular Jurisdiction within the Dominions of the Sultan of Muscat. November 4th 1867. F.O. 54/28.

52 Beachey, 1976, p. 78.

53 Cooper, F., 1977, Plantation Slavery on the East Coast of Africa. London, p. 37.

54 Parliamentary Papers. "Slave Trade”. Report of the Select Committee, 4th August 1871 vol. xii 1871.

55 Ibid. See the same Report.
} 
passes for Lamu and then northwards, taking their chance of escaping the British search. Buxton, confirmed the British authorization of their ships' patrol on the East African Coast, which should by now have produced more effective action than they had before. ${ }^{56}$ Recognized tactics were employed to avoid capture by the British cruisers on the East African Coast, and there was no need for more than deploying some vessels from the Royal Navy to watch the straits in these waters during the seasons of the trade which were dependent upon the monsoon.

Those principally accused of perpetrating the trade were Arabs of the Persian Gulf and Oman, who shipped slaves from Zanzibar for sale. On January the 24th 1870 the committee on East Africa H. Y. A. Churchill, Henry Fairfax, I. W. M. Kaye, Secretary of State, for Foreign Affair George William Clarendon, and confirmed that this trade was chiefly in the hands of northern Arabs, whose object was to purchase if they could, but if they did not they usually kidnapped the slaves they might need, and then exported them to the Red Sea, Arabia, and the Persian Gulf. ${ }^{57}$

The annual number of slaves shipped was difficult to confirm, but it was estimated that a number from 10,000 to 11,000 were still shipped for the slave markets in Arabia and some other ports in the Gulf. ${ }^{58}$ Despite the involvement of the northern Arabs in this trade, it was true that their intention was to trade legally with East Africa, but not in slaves. So undoubtedly they had generally been persuaded by the natives of East Africa who found the trade in this commodity more profitable to them. By this time the British were convinced that within the next few years the traffic in slavery could be brought under tighten control, and the people of Zanzibar had begun to realize that the British were right in their efforts to prohibit the entire trade between the Arabs and East Africa. ${ }^{59}$ In consideration of this fact the British Government was seeking more co-operation between them and the countries whose subjects were involved in this matter. Formally there was no Vice-Admiralty Court in these waters, which could bring more action to bear on the traffic: it was not until 1871, that the Vice-Admiralty Courts were established at Aden, Zanzibar and Muscat. These Courts required that the crews of the captured dhows must be sent along with the vessel to the court in the port of adjudication. ${ }^{60}$

The jurisdiction of Muscat was confined to the case of dhows captured within the following area: the Gulf of Oman, the Persian Gulf, and to north of the Equator and east of the longitude of Cape Guardafui. Under these circumstances the dhows captured on the coast of Arabia, between the longitude of 55 degree and 60 degree should be taken either to the Muscat or Aden Court depending on the location of the seizure. ${ }^{61}$ In accordance to these measures, the confirmed practice was that any captured vessels dealing in the slave trade would instantly be destroyed, depending on the opinion of the capturing Officer. ${ }^{62}$

Zanzibar was now obliged to be effective against this trade by various Parliamentary Acts and Orders in Council, which authorized the establishment of Courts of Jurisdiction. The British found that the extension of these regulations to the northern Arabs could be only achieved by the presence of the Royal Navy in East African seas, and at the Indian Ocean stations, which would certainly be sufficient to prohibit the passage of the traffic

\footnotetext{
56 The Times Newspaper, II Slave Trade in the Indian Ocean. London; 14th April 1873.

57 Parliamentary Papers. “Slave Trade”. Report of the Select Committee, January 4th 1872. vol. lxi, C. 209.

58 Ibid. See the same Report.

59 RusseIl, 1935, pp. 210-211; See also Berlioux, E. F., The Slave Trade in Africa in 1872. London; 1971, p. 52.

60 I. O. R. Mss. Bur. F126/14. Report from the British Political Resident in the Persian Gulf; Lewis Pelly to the Government of Bombay for the year 1872 .

61 I. O. R. Mss. Bur. F126/14. See the same Report. See also the Parliamentary Papers. “Slave Trade” vol. lxi, C. 209.

62 Parliamentary Papers. See the same Report. vol. lxi, C. 209.
} 
from Africa to Arabia. ${ }^{63}$ In May 1871, Sultan Turki b. Said issued an anti-slavery proclamation which was considered to be one of the most advanced steps in combating the traffic in the country. He stated the following:

The owners or masters of all vessels which shall arrive in any part of our possessions with slaves imported for sale shall be liable to punishment, and we order such vessels to be burnt on the facts being established; any person concerned in landing slaves as aforesaid shall be punished. No person is permitted to traffic with such vessels, and whoever shall aid them, conceal their affairs, or land slaves in any place, shall be punished by us. ${ }^{64}$

A complete suppression of the traffic however was really not an easy task to be achieved either by the British or the Government of Muscat or Zanzibar.

On 20th August 1872 the British Political Resident in the Gulf communicated with the Sultan of Muscat, SayyidTurki, to attract his attention to Her Majesty’s Government's anxiety over the continuation of the slave traffic from the East African Coast by the Arabs of Oman. Pelly added that the Arabs of the Gulf were also, under the British scrutiny, and were fully encouraged by their local Governments to undertake more action against this matter. ${ }^{65}$ The Resident reminded the Sultan of his country's previous obligations entered into by the ruling dynasty of Oman with the British Government for the purpose of ending the trade. He praised the Sultan's action and efforts over the issue and confirmed his approval of the Sultan's attention to these difficulties. The Sultan was persuaded to exercise more action, and was induced to prevent the import of slaves either to his sphere of influence or in transit through his dominions to any different part of the Gulf. ${ }^{66}$

British officials thought carefully about this question from now onward, as it appeared to be one of the major challenges to their policy in the area. In November 1872, the Duke of Argyle was ordered to join an anti-slavery mission to the East African Coast under Sir Bartle Frere, to enable him to form his own view on the slave trade. He accompanied Frere on board the Admiralty Yacht Enchantress to Zanzibar, Mozambique, Madagascar, the Comoro Islands, the East Coast of Mrica, Mukalla, and finally to Muscat. ${ }^{67}$ The British Political Resident Lewis Pelly supplied the mission with every cooperation and had been working vigorously with the British Government in anticipation of instructions, to obtain effective action from the people of the Gulf to prohibit the trade in their territories. These steps were considered as a great achievement towards the conclusion of the Treaty of April 1873 with Sultan Turki b. Said. ${ }^{68}$

Despite these activities, however, information about the trade was insufficient, and the campaign against it was in difficulties. However, the activities of the Royal Navy ships off the Omani coasts during the second half of the nineteenth century were more effective than before. H. M. ship Queen which had begun its service in July 1855 off the Omani coasts between Ras al-Hadd and Muscat performed with distinction against the trade. ${ }^{69}$ In June 1872, H. M. S. Magpie was able to capture three slave ships off Ras al-Hadd, and 62 slaves were set free. A

\footnotetext{
${ }^{63}$ Parliamentary Papers. Report of the Select Committee, 9th February to 21st August, 1871. vol. xii. See also Saldanha Précis on Slave Trade. p. 25.

64 I. R. O. 1867-1947. vol. Precisof Muscataffairs 1869-1872. p. 478.

${ }^{65}$ I. O. R. R/15/6/5. Letter from British Political Resident in the Persian Gulf, to H. H. SayyidTurki b. Said Sultan of Muscat. Dated Bushire, 15th August 1872.

${ }^{66}$ I. O. R. R/15/6/5. See the same letter.

67 I. O. R. Mss. Bur. F126/14. Report from British Political Resident in the Persian Gulf; Col. L. Pelly, to the Government of Bombay for the year 1872 .

${ }^{68}$ I. O. R. Mss. Bur. F126/14. See the same Report.

${ }^{69}$ Lorimer, 1915, vol. I, p. 2492.70 ibid. p. 2493.
} 
similar case occurred in September 1872, when H.M.S. Vulture captured another Omani dhow carrying 169 slaves, mostly women and children. Accordingly the Sultan imprisoned the Nokhada of the Baghlah, which was destroyed by the Sultan's order. ${ }^{70}$

The British authorities had borne the greater part of the burden of destroying illegal trade, on the coasts of both Africa and Arabia, since the early nineteenth century. Their activities had exercised a great influence on the local authorities to persuade them to be more involved in action against the traffic, and to induce them to conform with British wishes. The Sultan of Muscat SayyidTurki remained in active cooperation with all actions undertaken by the British on this matter, and SayyidTurki established a close understanding with the British by accepting their activities off his coasts with respect to any action against those involved in slavery.

The Sultan also agreed to prohibit the open markets of slaves in his dominions, and showed no objection to any action taken against his subjects who were involved in the traffic. For example, in October 1872 H. M. S. Wolverine captured one of the Sultan's subjects accused of landing some slaves and selling them in the public market. Accordingly the Government of Bombay ordered the British Political Agent at Muscat to investigate the situation strictly. Sultan Turki showed no objection, and offered a necessary information, but the Agent found no confirmation regarding these allegations at the end of his investigation in February $1873 .^{71}$

However, the slave-trade generally remained a very ambiguous topic, and the smuggling of slaves was one of the important points in Sultan Turki's relations with British, who was looking for more successful cooperation with him to bring the matter to an outstanding conclusion.

\section{Bibliography}

\section{Primary Sources}

\section{Unpublished Document, Manuscript and collections}

1- India Office Record (I. O. R).

European Manuscripts Collections (Eur. Mss.).

Eur. Mss. F126 Sir Lewis Pelly collection (1825-1892).

Ms. No. 12659. Summary of the Proceedings of the Government of India in the Foreign Department during the Viceroyalty of his Excellency the Earl of Minto. November 1905-March 1906. April 1906-March1907. April 1907-March 1908.

Ms. No. 12593. Summary of the Principal Events and measure of the Viceroyalty of His Excellency Lord Curzon of Kedleston; (Foreign Department). Part i. January 1899-April 1904. Part .ii. December 1904-November 1905.

\section{Political and Secret Department Records.}

L/P-S/3. Secret Home Correspondence, 1839-1874.

L/P-S/5. Secret letters to India, Madras, Bombay, Aden, Muscat Persian Gulf and Zanzibar 1859-1874.

L/P-S/7. Political and Secret Correspondence with India 1875-1911.

R/15/6. Political Agency Muscat (PAM) 1800-1951 (549 vols.).

2- Public Records Office (F.O).

F.O. 84 Slave Trade.

F. O. 54 Muscat (1834-1905).

\section{Published Archives, Digests and Documents.}

${ }^{70}$ I. R. O. vol. ii, Précis of Muscat affairs 1872-1892. p. 30.

71 Administration Report of the Persian Gulf Political Residency and Muscat Agency for the year 1873-1874. vo1. I, p. 74. 
Aitchison, C. U. (1983). A Collection of Treaties Engagements and Sanads Relating to India and Neighbouring Countris, xiv. vols, New Delhi.

Baily, R. W. (ed.). (1988). Record of Oman (R.O.), 1867-1947. (12vols). London.

Great Britain. Parliamentary Papers, vol. lxi. London. 1870.

- Parliamentary Papers, vol. lxii. London. 1871.

- Parliamentary Papers, vol. lxxi. London. 1875.

Parliamentary Papers, vol. lxxii. London. 1878.

Parliamentary Papers The Zanzibar Papers 1841-98. London. 1914.

Lorimer J. G. (1915). Gazetteer of the Persian Gulf; Oman and Central Arabia, Calcut, Iv.Vols.

Records of the Government of India (Foreign Department) Administration Report on the Persian Gulf Political Residency and Muscat Political Agency. (12 vols.).

Saldanha, J. A. (1906). Précis on Slave Trade in the Gulf of Oman and the Persian Gulf, 1873-1905, with a Retrospect into previous history from 1856, Simla.

Tuson, P., \& Quick, E. (eds.). (1992). Arabian Treaties 1600-1960. vol. iii. Oman and Yemen, London.

\section{Secondary Sources:}

\section{Books:}

Alpers, E. A. (1975). Ivory and Slaves in East Central Africa, Nairobi.

Bader Z. (1982). The Contradictions of Merchant Capital 1840-1939. (ed.) Abdul Sheriff \& Ferguson, Zanzibar under Colonial Rule, London.

Olson, W. J. (1982). Britain’s Elusive Empire in the Middle East, 1900-1921, London.

Beachey, R. W. (1976). The Slave Trade of Eastern Africa, London.

Berlioux, E. F. (1971). The Slave Trade in Africa in 1872, London.

Bhacker, M. Reda. (1988). Roots of Dependency British Reaction towards the Development of Omani Commerce at Muscat. Ph.D. Thesis. Oxford.

Coen, T. C. (1971). The Indian Political Service, London.

Cooper, F. (1977). Plantation Slavery on the East Coast of Africa, London.

Cox, Sir P. (1925). Some Excursions in Oman, G. J. vol. lxvi, No. 3.

Datoo, B. A. (1970). Misconceptions about the use of the monsoons by Dhows in the East African Waters. East African Geographical Review 8, 1-10.

Harris, J. E. (1971). The African Presence in Asia, Evanston.

Ingham, K. (1962). Short History of East Africa, London.

Kelly, J. B. (1968). Britain and the Persian Gulf 1795-1880, Oxford.

Lloyd, C. (1949). The Navy and the Slave Trade, London.

Martineau, J. (1895). The 1ife and Correspondence of Sir Bartle Frere, ii.vols, London.

Miers, S. (1975). Britain and the Ending of the Slave Trade, London.

Miles, S. B. (1919). The Countries and the Tribes of the Persian Gulf, London.

Olson, W. J. (1982). Britain's Elusive Empire in the Middle East, 1900-1921, London.

Russell, C. E. B. (1935). General Rigby, Zanzibar and the Slave Trade, London.

Philby, H. (1952). Arabian Jubilee, London. 